ORNL/TM-2005/193

\title{
Blend Down Monitoring System Fissile Mass Flow Monitor Implementation at the ElectroChemical Plant, Zelenogorsk, Russia
}

\section{November 2005}

Taner Uckan, José March-Leuba, Danny Powell, and Michael Wright (ORNL)

Joseph Glaser (DOE) 


\title{
DOCUMENT AVAILABILITY
}

Reports produced after January 1, 1996, are generally available free via the U.S. Department of Energy (DOE) Information Bridge:

Web site: http://www.osti.gov/bridge

Reports produced before January 1, 1996, may be purchased by members of the public from the following source:

\author{
National Technical Information Service \\ 5285 Port Royal Road \\ Springfield, VA 22161 \\ Telephone: 703-605-6000 (1-800-553-6847) \\ TDD: $703-487-4639$ \\ Fax: 703-605-6900 \\ E-mail: info@ntis.fedworld.gov \\ Web site: http://www.ntis.gov/support/ordernowabout.htm
}

Reports are available to DOE employees, DOE contractors, Energy Technology Data Exchange (ETDE) representatives, and International Nuclear Information System (INIS) representatives from the following source:

Office of Scientific and Technical Information

P.O. Box 62

Oak Ridge, TN 37831

Telephone: 865-576-8401

Fax: 865-576-5728

E-mail: reports@adonis.osti.gov

Web site: http://www.osti.gov/contact.html

This report was prepared as an account of work sponsored by an agency of the United States government. Neither the United States government nor any agency thereof, nor any of their employees, makes any warranty, express or implied, or assumes any legal liability or responsibility for the accuracy, completeness, or usefulness of any information, apparatus, product, or process disclosed, or represents that its use would not infringe privately owned rights. Reference herein to any specific commercial product, process, or service by trade name, trademark, manufacturer, or otherwise, does not necessarily constitute or imply its endorsement, recommendation, or favoring by the United States government or any agency thereof. The views and opinions of authors expressed herein do not necessarily state or reflect those of the United States government or any agency thereof. 
Nuclear Science and Technology Division

\title{
Blend Down Monitoring System Fissile Mass Flow Monitor Implementation at the
} ElectroChemical Plant, Zelenogorsk, Russia

\author{
Taner Uckan, José March-Leuba, Danny Powell, and Michael Wright (ORNL) \\ Joseph Glaser (DOE)
}

Date Published: November 2005

Prepared by the

OAK RIDGE NATIONAL LABORATORY

Oak Ridge, Tennessee 37831-6283

managed by

UT-BATTELLE, LLC

for the

U.S. DEPARTMENT OF ENERGY

under contract DE-AC05-00OR22725 



\section{CONTENTS}

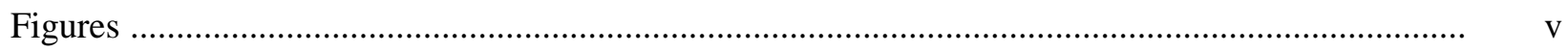

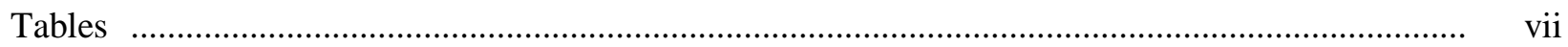

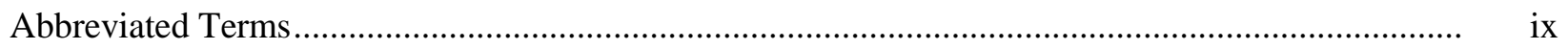

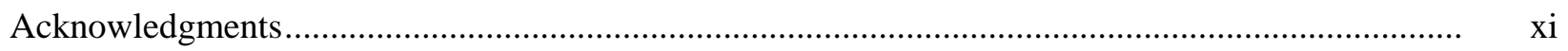

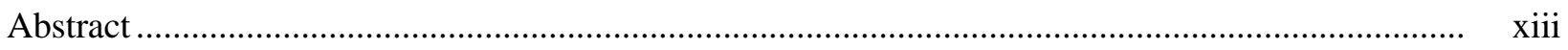

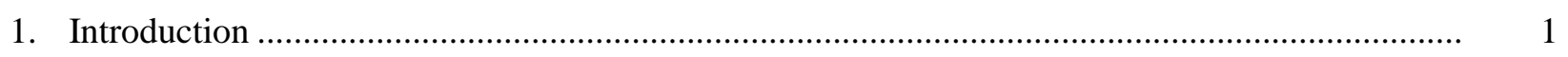

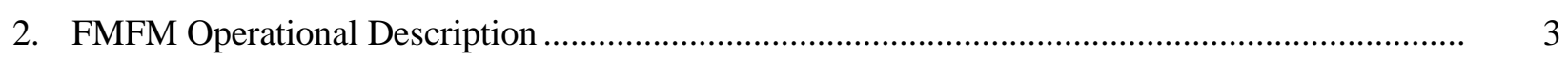

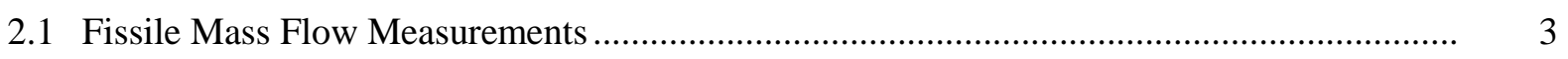

2.2 HEU Traceability Measurements................................................................................ 5

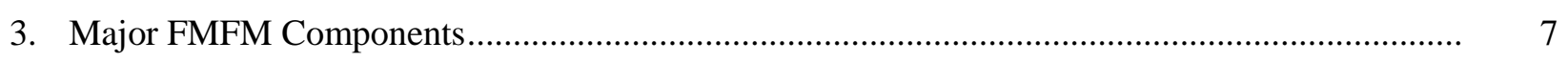

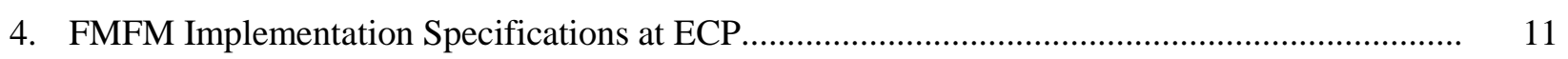

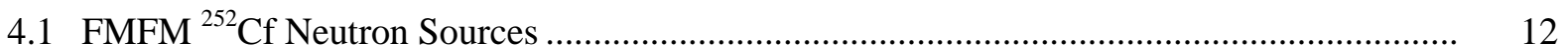

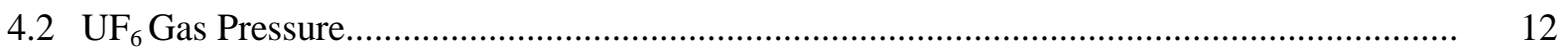

4.3 FMFM Flow Regime Operations and $\mathrm{UF}_{6}$ Gas Velocity ….............................................. 12

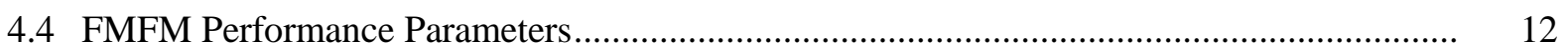

4.5 Recommended FMFM Equipment Installation Configuration at ECP ............................... 13

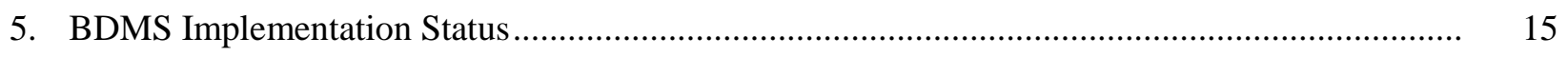

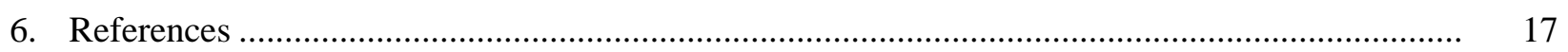





\section{FIGURES}

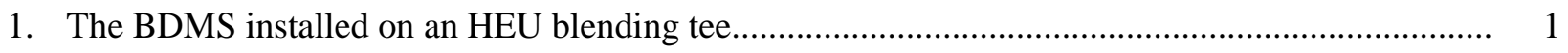

2. The FMFM operational principle and major components ......................................................... 3

3. The FMFM-measured detector signal waveform and the detector counts are collected

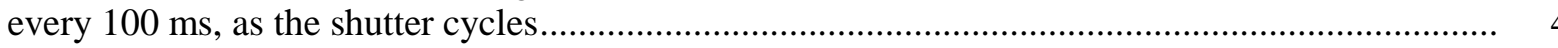

4. The FMFM HEU leg shutter motion pattern used to generate the low-frequency modulation required for the tracing of the HEU flow to the P-LEU leg ...................................... 5

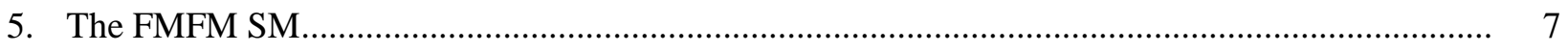

6. Details of the FMFM SM assembly and components ........................................................ 7

7. The FMFM detector assembly showing the DIEC and the gamma shield ................................... 8

8. The FMFM SM assembly with the shutter positioner together with its motor

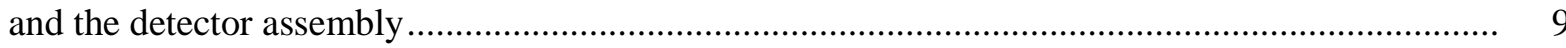

9. The BDMS main cabinet housing the FMFM (left) and EM (right) cabinet sections .................... 9

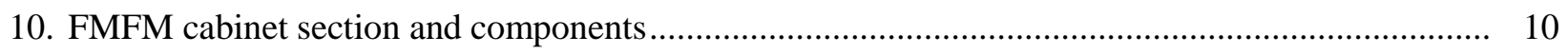

11. Block diagram of the BDMS equipment installation on the HEU blending system at ECP ........... 11

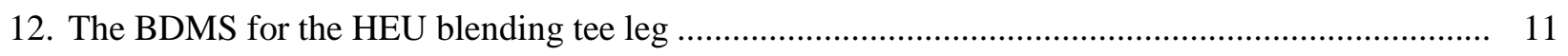

13. Recommended FMFM installation configuration for HEU leg ................................................ 13

14. Recommended FMFM installation configuration for the LEU and P-LEU legs ........................... 13

15. Recommended FMFM installation configuration for all legs ................................................. 14

16. The ECP BDMS training for the Russian delegation at ORNL, March 18-27, 2002 ................... 15 



\section{TABLES}

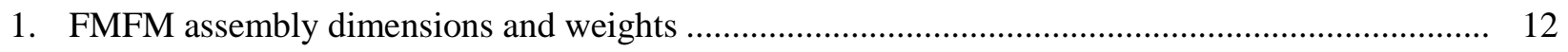

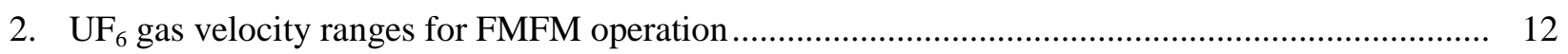

3. FMFM flow measurement range and associated uncertainty ............................................... 13 



\section{ABBREVIATED TERMS}

$\begin{array}{ll}\text { BDMS } & \text { Blend Down Monitoring System } \\ \text { BGO } & \text { bismuth germanium oxide } \\ \text { DIEC } & \text { detector interface electronics card } \\ \text { DOE } & \text { U.S. Department of Energy } \\ \text { ECP } & \text { Electro Chemical Plant (Zelenogorsk) } \\ \text { EM } & \text { Enrichment Monitor } \\ \text { FMFM } & \text { Fissile Mass Flow Monitor } \\ \text { HEU } & \text { highly enriched uranium } \\ \text { LEU } & \text { low enriched uranium } \\ \text { MINATOM } & \text { Ministry for Atomic Energy of the Russian Federation } \\ \text { ORNL } & \text { Oak Ridge National Laboratory } \\ \text { P-LEU } & \text { product low enriched uranium } \\ \text { PMT } & \text { photomultiplier tube } \\ \text { SM } & \text { source modulator } \\ \text { UEIP } & \text { Ural Electrochemical Integrated Plant (Novouralsk) }\end{array}$





\section{ACKNOWLEDGMENTS}

The authors wish to thank Kim N. Castleberry, Richard W. Jones, and Carl W. Martin (Engineering Science and Technology Division) for their tireless work on the BDMS FMFM equipment. 



\begin{abstract}
The implementation plans and preparations for installation of the Fissile Mass Flow Monitor (FMFM) equipment at the ElectroChemical Plant (ECP), Zelenogorsk, Russia, are presented in this report. The FMFM, developed at Oak Ridge National Laboratory, is part of the Blend Down Monitoring System (BDMS), developed for the U.S. Department of Energy Highly Enriched Uranium (HEU) Transparency Implementation Program. The BDMS provides confidence to the United States that the Russian nuclear facilities supplying the lower-assay ( 4\%) product low enriched uranium (P-LEU) to the United States from down-blended weapons-grade HEU are meeting the nonproliferation goals of the government-togovernment HEU Purchase Agreement, signed between the Russian Federation and the United States in 1993. The first BDMS has been operational at Ural Electrochemical Integrated Plant, Novouralsk, since February 1999 and is successfully providing HEU transparency data to the United States. The second BDMS was installed at ECP in February 2003. The FMFM makes use of a set of thermalized californium$252\left({ }^{252} \mathrm{Cf}\right)$ spontaneous neutron sources for a modulated fission activation of the $\mathrm{UF}_{6}$ gas stream for measuring the ${ }^{235} \mathrm{U}$ fissile mass flow rate. To do this, the FMFM measures the transport time of the fission fragments created from the fission activation process under the modulated source to the downstream detectors by detecting the delayed gamma rays from the fission fragments. The FMFM provides unattended, nonintrusive measurements of the ${ }^{235} \mathrm{U}$ mass flow in the HEU, LEU blend stock, and P-LEU process legs. The FMFM also provides the traceability of the HEU flow to the product process leg. This report documents the technical installation requirements and the expected operational characteristics of the ECP FMFM.
\end{abstract}





\section{INTRODUCTION}

The Highly Enriched Uranium (HEU) Transparency Agreement between the United States and the Russian Federation requires implementation of transparency measures in the Russian facilities that are supplying the lower-assay product low enriched uranium (P-LEU) to the United States from downblended weapon-grade HEU material. Moreover, the agreement provides for the monitoring of the downblending of HEU at an assay of $\sim 90 \%$ with blend stock LEU at an assay of $\sim 1.5 \%$ to produce P-LEU at an assay of $\sim 4 \%$ (reactor-grade material), to be used in U.S. nuclear power plants. The Ministry for Atomic Energy of the Russian Federation (MINATOM) and the U.S. Department of Energy (DOE) have agreed on implementing transparency measures at the Ural Electrochemical Integrated Plant (UEIP), at Novouralsk, Russia, and at the Electro Chemical Plant (ECP), at Zelenogorsk, Russia.

The transparency measures include the installation of the Blend Down Monitoring System (BDMS) to monitor the enrichment and fissile mass flow of the HEU blending processes at UEIP and at ECP. The BDMS has been developed to provide unattended and continuous monitoring of the blending operations at the Russian facilities. The BDMS consists of the Fissile Mass Flow Monitor (FMFM), which was developed at Oak Ridge National Laboratory (ORNL) [1], and the Enrichment Monitor (EM), which was developed at Los Alamos National Laboratory [2]. The FMFM provides unattended measurements of ${ }^{235} \mathrm{U}$ mass flow of the uranium hexafluoride $\left(\mathrm{UF}_{6}\right)$ gas in the process legs that carry the HEU, the LEU blend stock, and the resulting lower-assay P-LEU. The FMFM also traces fission products generated in the HEU flow through the blending operation into the P-LEU flow, thus confirming that the HEU material is down-blended (Fig. 1).

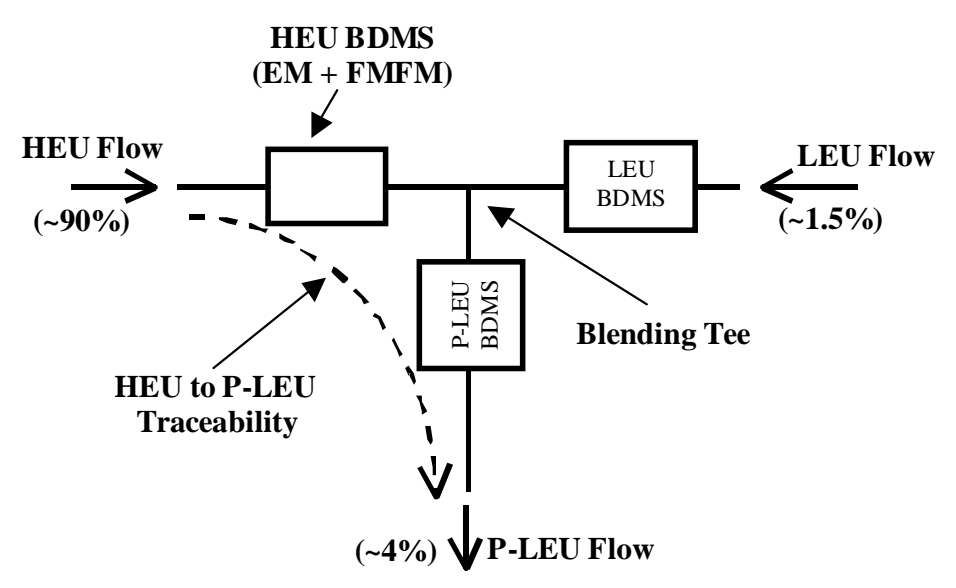

Fig. 1. The BDMS installed on an HEU blending tee. 
Traceability of HEU material gives the United States significant confidence that the HEU is indeed being blended into a lower-assay material. The first BDMS was successfully implemented at the UEIP and has been operational since February 1999. As part of the Transparency Implementation Program, DOE is continuing to implement FMFM instrumentation for the rest of the Russian nuclear facilities that are supplying the down-blended HEU material for the purchase agreement. The primary topic of this report is the FMFM implementation at the ECP HEU blending facility. 


\section{FMFM OPERATIONAL DESCRIPTION}

\subsection{FISSILE MASS FLOW MEASUREMENTS}

As shown in Fig. 1, the FMFM measures the fissile mass flow of the $\mathrm{UF}_{6}$ gas in the HEU, the P-LEU, and the LEU blend stock process legs of the blending tee. The main measurement principle for the FMFM relies on the production of fission fragments that are carried by the $\mathrm{UF}_{6}$ flow and that emit delayed gamma rays. To produce the fission fragments, thermalized neutrons (neutrons emitted by ${ }^{252} \mathrm{Cf}$ sources placed in an annular sleeve filled with moderator material that surrounds the pipe) are modulated by a neutron-absorbent shutter to induce fission in the $\mathrm{UF}_{6}$ (Fig. 2).

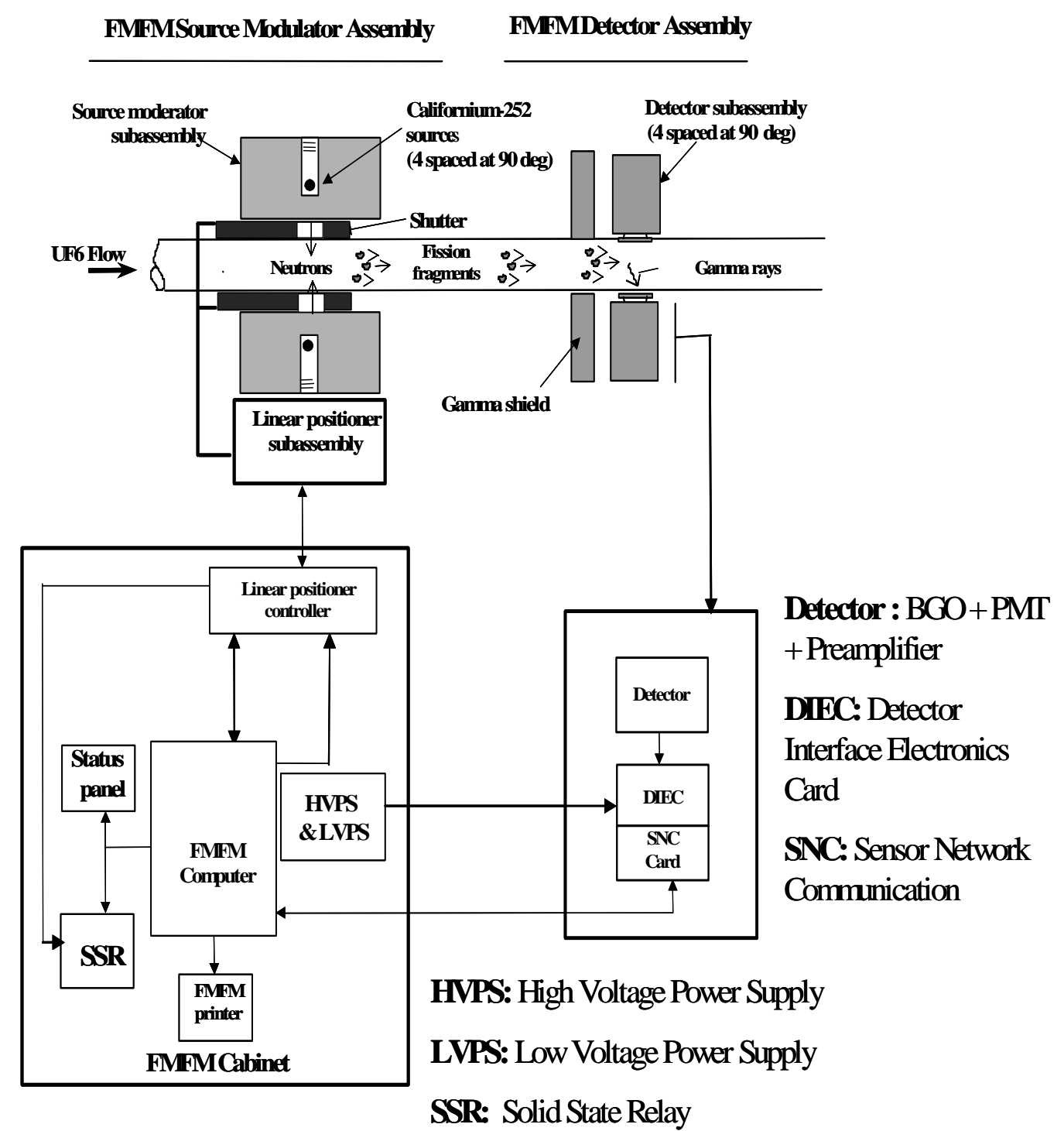

Fig. 2. The FMFM operational principle and major components. The source moderator is covered with lead and lithiated polyethylene shielding to achieve the facility dose rate requirement ( $0.3 \mathrm{mrem} / \mathrm{h}$ at $1 \mathrm{~m})$. 
The induced fissions are time-modulated by using a neutron-absorbing shutter to create a time signature in the $\mathrm{UF}_{6}$ gas flow. A gamma ray measuring detector (see Fig. 2), located downstream of the source modulator (SM), measures delayed gamma rays emitted by the resulting fission fragments. Then, the FMFM determines the fissile mass flow rate from two independent measurements: (1) the observed delay in the time-correlated measurement between the $\mathrm{SM}$ and the detector signal provides the velocity of $\mathrm{UF}_{6}$, and (2) its amplitude is related to the ${ }^{235} \mathrm{U}$ concentration in $\mathrm{UF}_{6}$ (see Fig. 3).

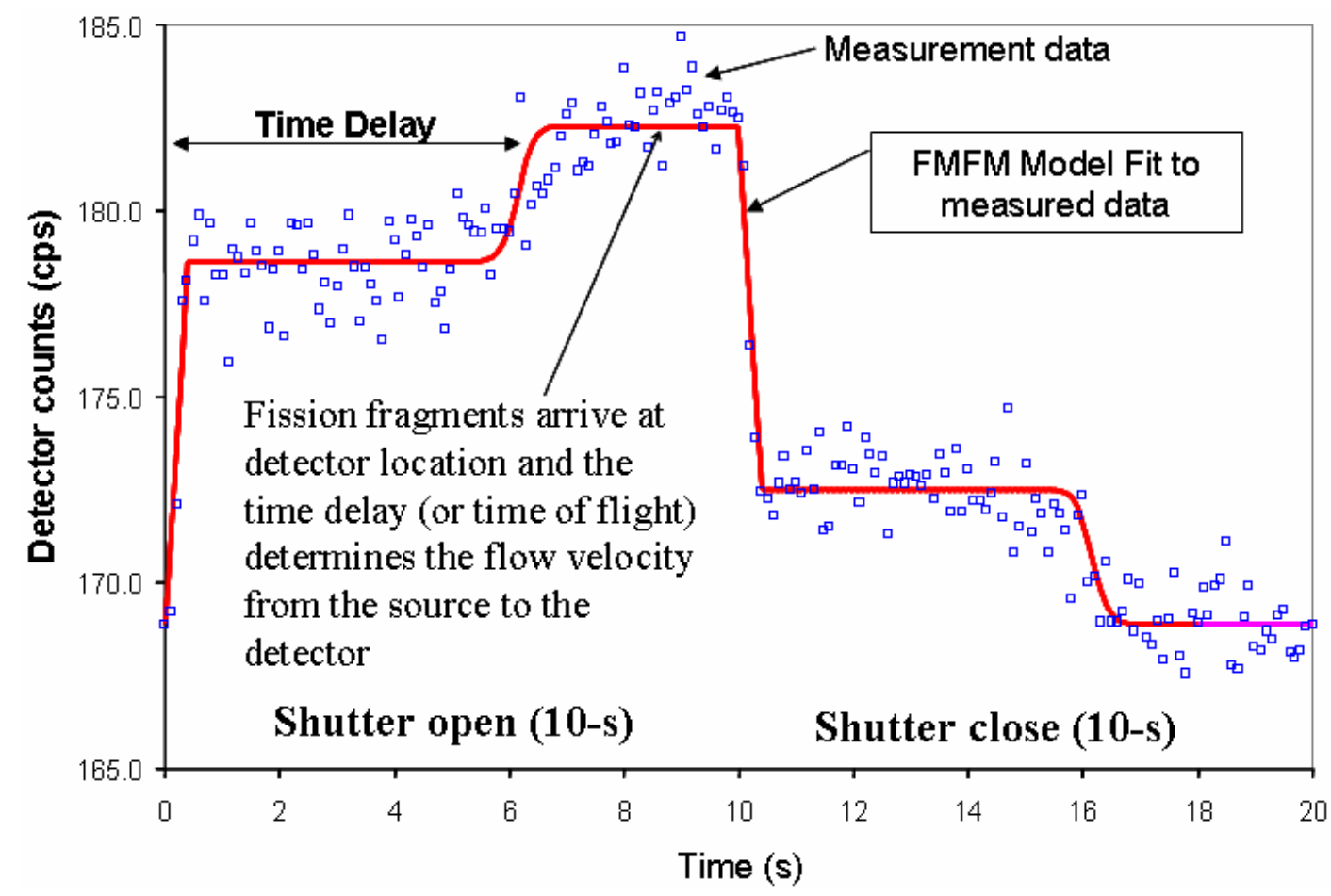

Fig. 3. The FMFM-measured detector signal waveform and the detector counts are collected every $100 \mathrm{~ms}$, as the shutter cycles.

To predict the detector response from the measurements of the gamma rays resulting from the fission fragment production downstream of the source, it is necessary to estimate (1) the fraction of fission fragments that remain in the $\mathrm{UF}_{6}$ gas following an induced fission by the ${ }^{252} \mathrm{Cf}$-neutron source, (2) the transport of the fission products in the pipe, and (3) the rate of decay of the fission products produced in the $\mathrm{UF}_{6}$ gas. The details of the FMFM models employed to predict the detector response are documented in other publications $[2,3,4]$. 


\subsection{HEU TRACEABILITY MEASUREMENTS}

The principle of the FMFM HEU traceability measurement is to trace the HEU material through the blending tee by detecting in the P-LEU leg detector delayed gamma rays emitted by fission products generated by the SM in the HEU leg (see Fig. 1). The fission fragments that are created from the ${ }^{252} \mathrm{Cf}-$ induced fissions are relatively long-lived [2]. Thus their delayed gamma rays can be detected at long distances from the source. This technique is used by FMFM to monitor flow continuity from the FMFM SM on the HEU leg to the detector on the P-LEU leg.

The FMFM tracing calculation is based on the difference in total count rate at the P-LEU detector with and without the HEU leg shutter in operation. The FMFM reports the HEU tracing results in terms of confidence level, which is a measure of the probability that the HEU flowed through the blending tee. The time constant for the low-frequency "tagging signal" must be optimized based on the source-detector time delay and on the number of mixing volumes. For the ECP system the FMFM cycles the HEU leg shutter open and closed every $10 \mathrm{~s}$ for a 10-min period and then closes it for the next 10-min period, as illustrated in Fig. 4. This operation results in a 20-min cycle of buildup and decay of fission products that allows for continuity monitoring by comparing the difference in the P-LEU leg detector counts with and without induced fissions.

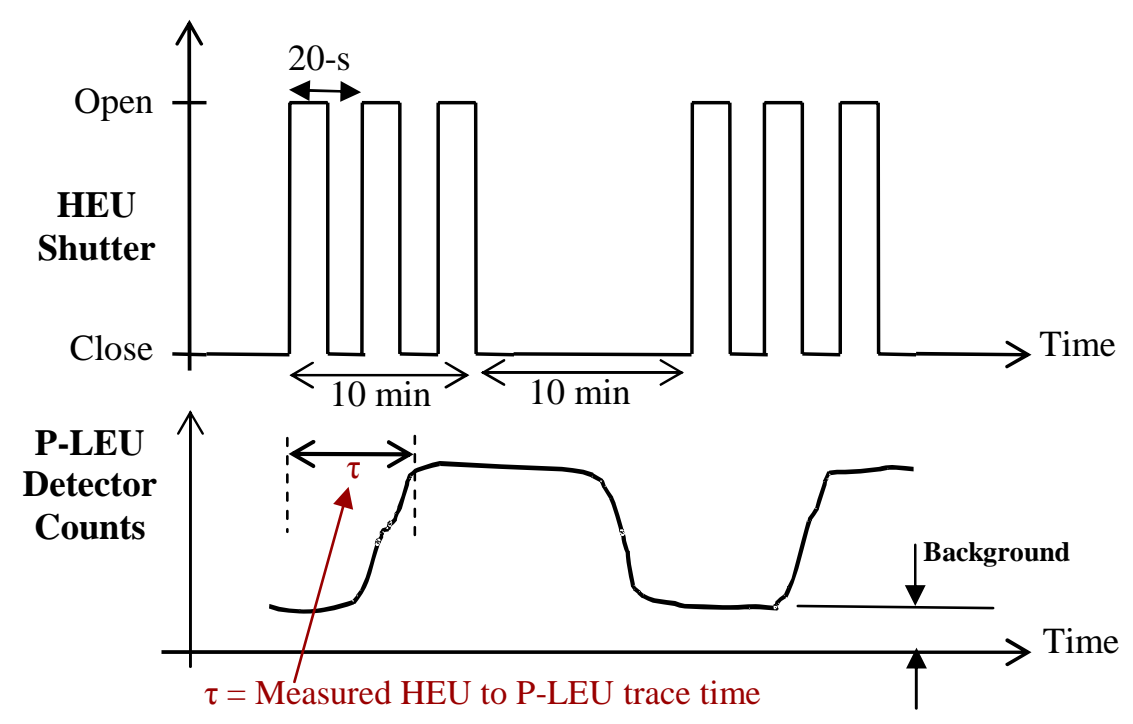

Fig. 4. The FMFM HEU leg shutter motion pattern used to generate the lowfrequency modulation required for the tracing of the HEU flow to the P-LEU leg. The traceability measurement is achieved by detecting the fission fragments tagged on the HEU flow stream with the P-LEU leg detector after a time delay, $\tau$. 
The periodic disabling the HEU-leg shutter (every other $10 \mathrm{~min}$ ) affects the shutter-correlated background level at the P-LEU leg detector. Therefore, the FMFM traceability only uses the data when all shutters are closed. An on-line FMFM computer synchronously controls the shutters on all three SMs, processes acquired detector data, and reports results on the flow and trace measurements. 


\section{MAJOR FMFM COMPONENTS}

The FMFM has three major components: the SM assembly, the detector assembly, and the control cabinet. Figure 2 shows a block diagram of all the pipe-mounted FMFM components for a single fissile flow stream. The SM assembly includes the ${ }^{252} \mathrm{Cf}$ sources, a polyethylene moderator, a neutron absorber shutter, and its associated shielding (Figs. 2, 5, and 6). The moderator subassembly, which contains the ${ }^{252} \mathrm{Cf}$ sources in source plugs, is shown in Fig. 5. The moderator is surrounded by lead and polyethylene shielding to minimize the radiation dose (see Figs. 5 and 6). The measured dose rate is less than 0.3 $\mathrm{mrem} / \mathrm{h}$ at any point $1 \mathrm{~m}$ from the $\mathrm{SM}$, and less than $10 \mathrm{mrem} / \mathrm{h}$ at any point in contact with the equipment. These dose rates meet all applicable requirements for the ECP facility installation.

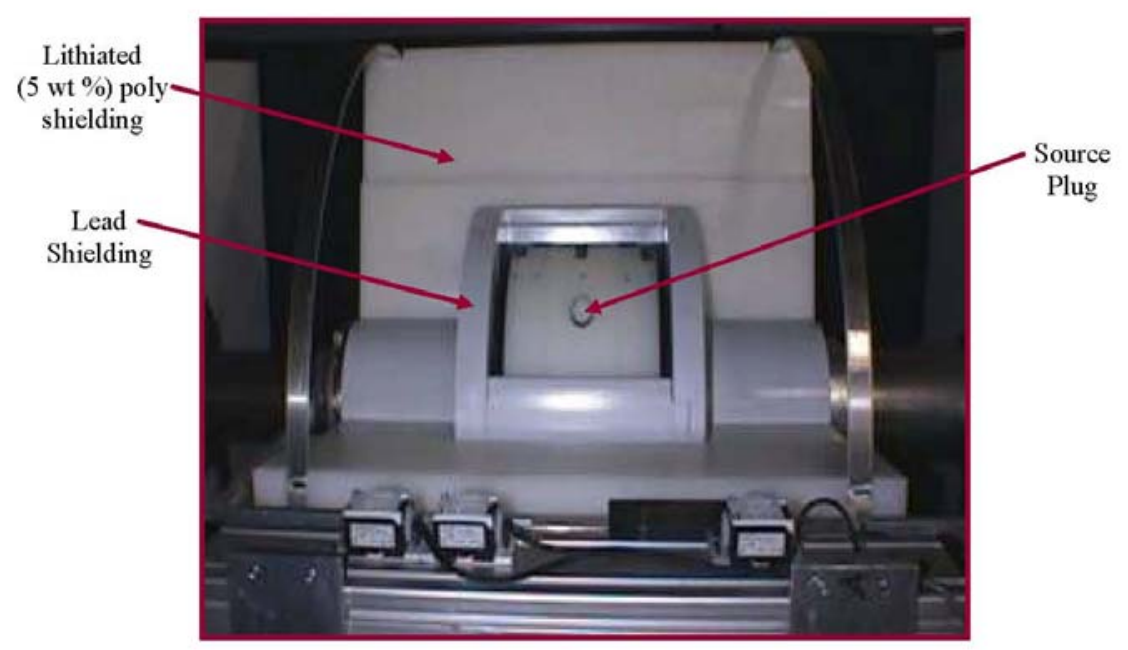

Fig. 5. The FMFM SM. Shown are the lead shielding covering the source moderator, the lithiated ( 5 weight $\%$ ) polyethylene shielding placed around the lead, and the shutter positioner.

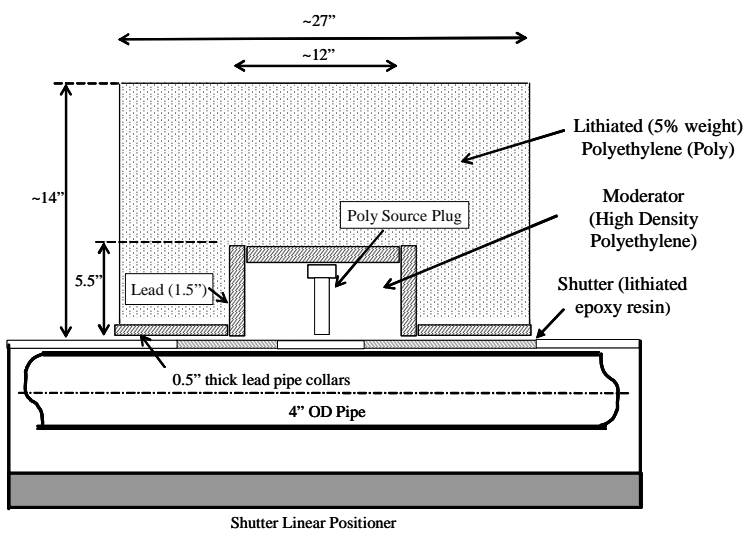

Fig. 6. Details of the FMFM SM assembly and components. Maximum allowable dose rates: 1 $\mathrm{mrem} / \mathrm{h}$ on surface and $<0.3 \mathrm{mrem} / \mathrm{h}$ at $1 \mathrm{~m}$. 
The detector assembly is composed of four bismuth germinate oxide (BGO) detectors that surround the pipe. The detector crystals and the photomultiplier tubes (PMTs) are surrounded by lead shielding to minimize room-background effects (see Figs. 2 and 7). In addition, a 3-in. circular gamma shield placed upstream minimizes the radiation background induced by the ${ }^{252} \mathrm{Cf}$ source (see Fig. 7). Each detector subassembly is fitted with a detector interface electronics card (DIEC), as shown in Figs. 2 and 7, which contains the signal-conditioning and discrimination amplifiers. The interface card also includes an onboard computer, which controls its operation and collects detector counts that are periodically downloaded to the main computer in the cabinet for processing.

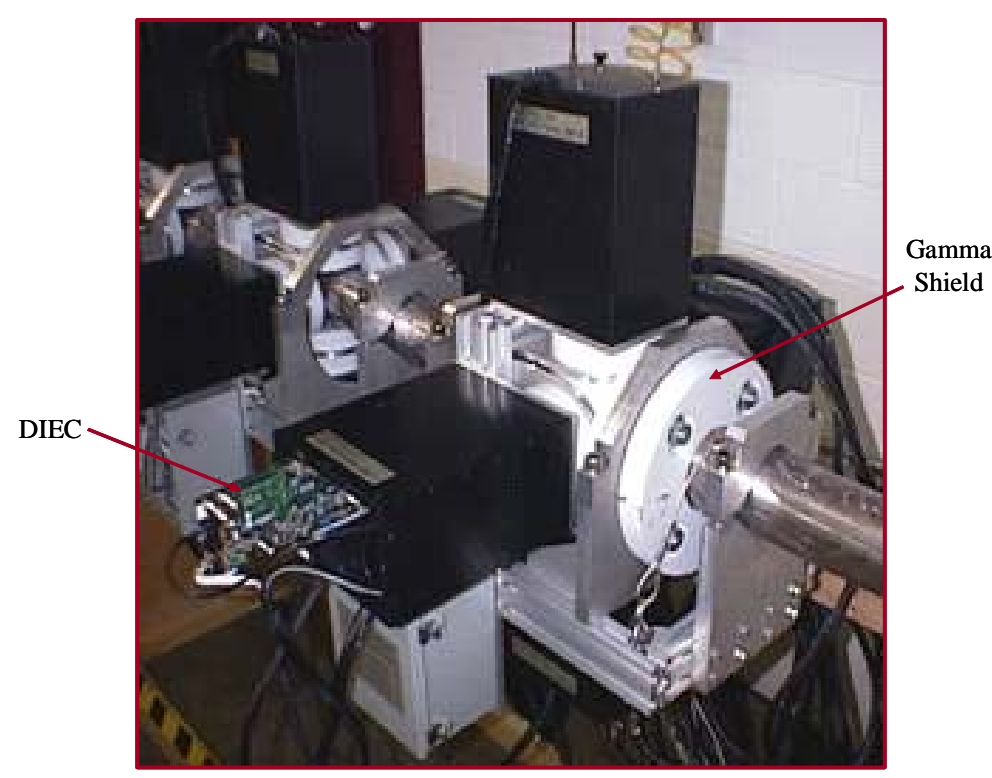

Fig. 7. The FMFM detector assembly showing the DIEC and the gamma shield.

The pipe-mounted SM and detector assembly shown in Fig. 8 represents a typical HEU leg configuration. The control cabinet provides power conditioning and distribution, control, and data acquisition and processing. Figure 9 shows the BDMS main cabinet installed at ECP. The FMFM cabinet section is on the left; the EM cabinet section is on the right. The details of the FMFM cabinet and its components are shown in Fig. 10. 


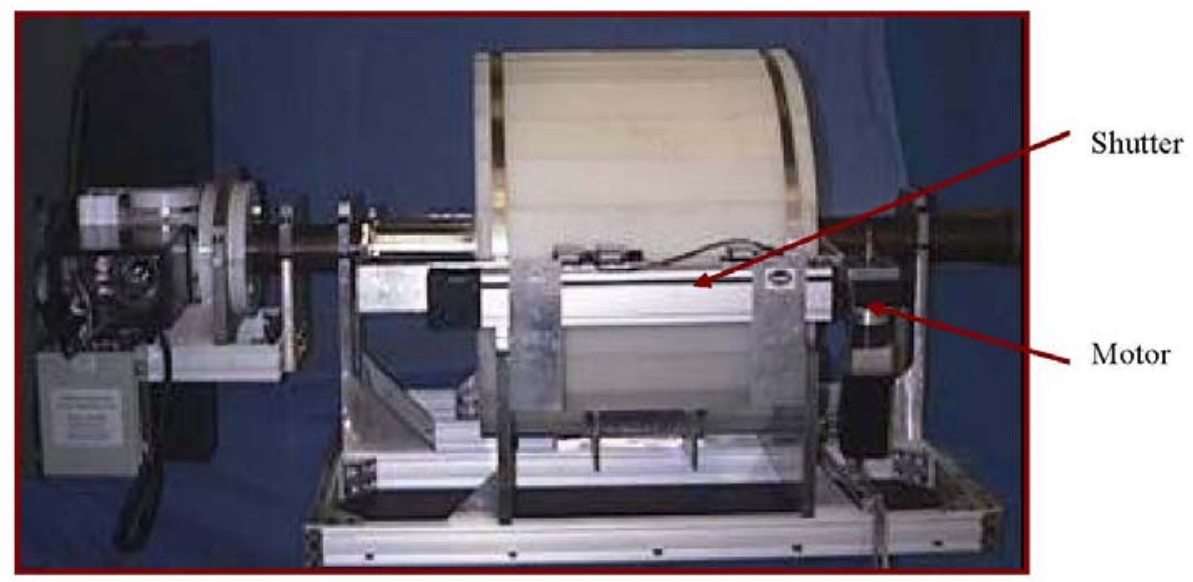

Fig. 8. The FMFM SM assembly with the shutter positioner together with its motor and the detector assembly.

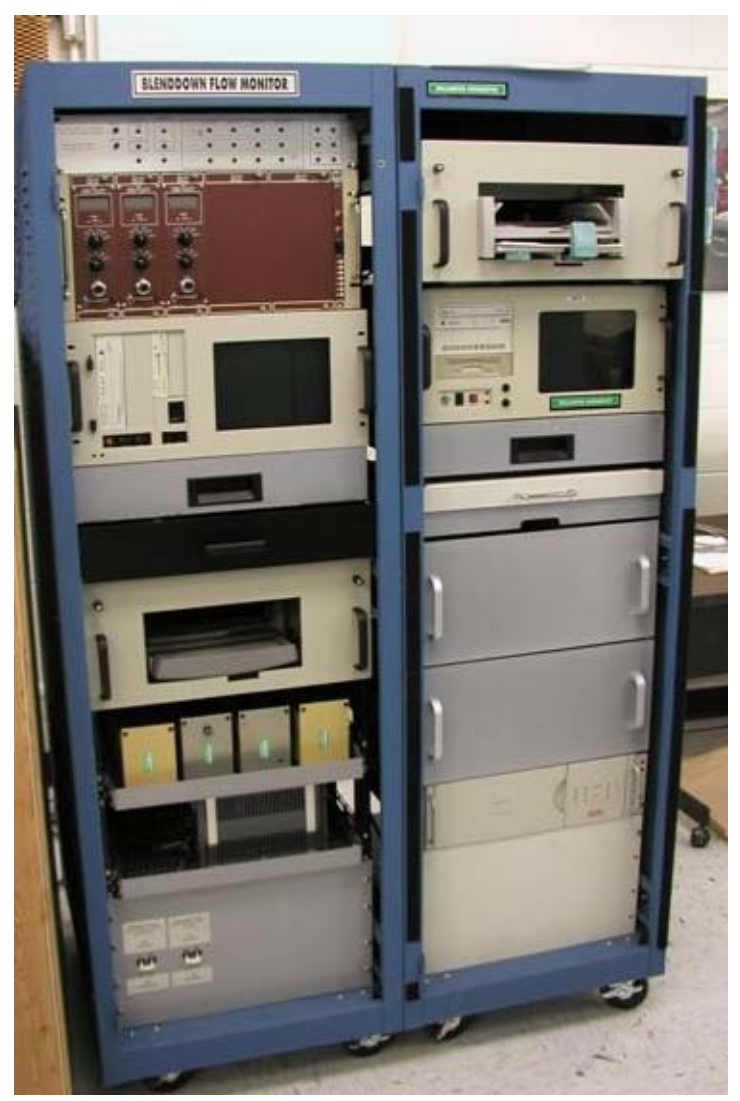

Fig. 9. The BDMS main cabinet housing the FMFM (left) and EM (right) cabinet sections. 


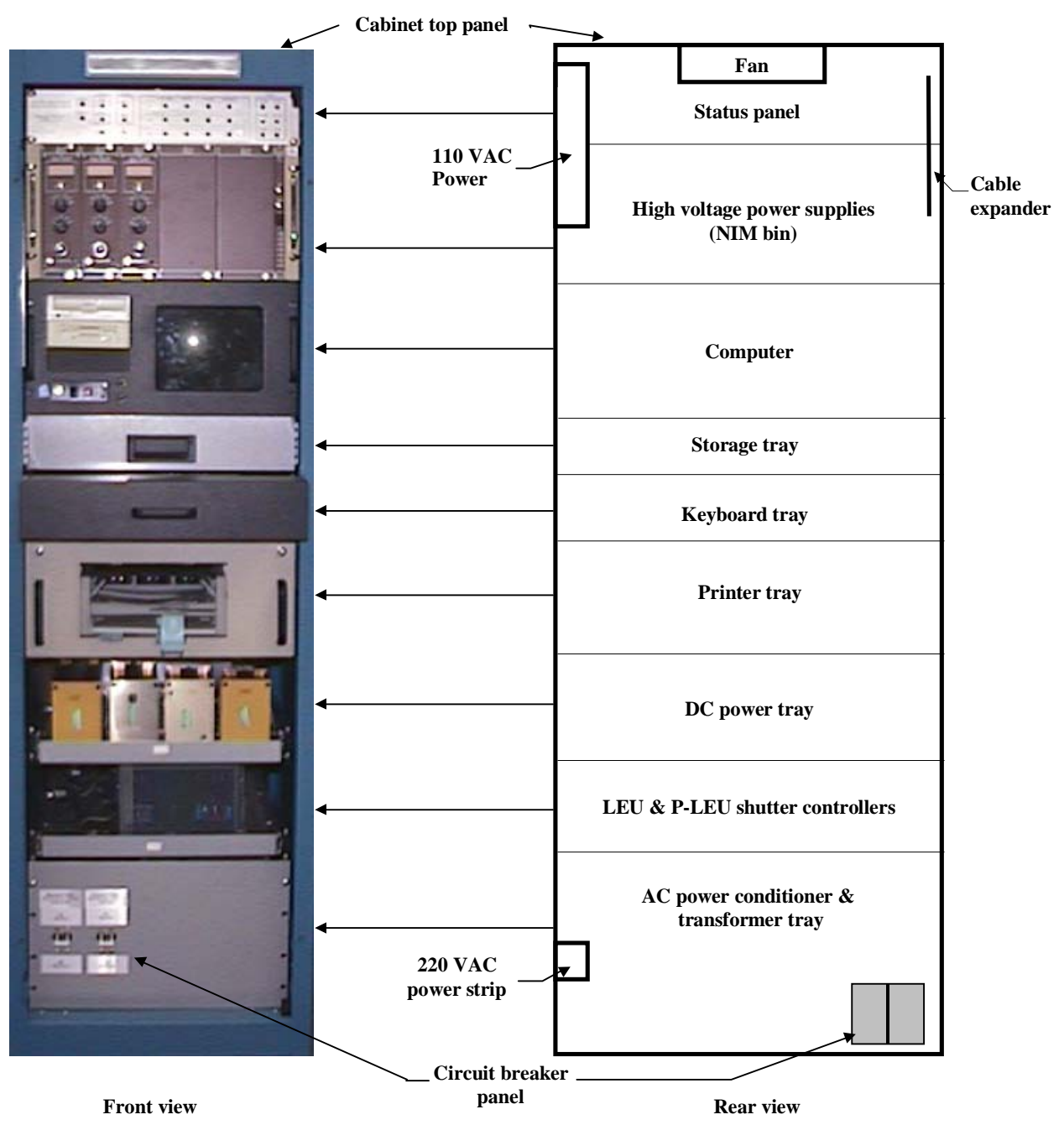

Fig. 10. FMFM cabinet section and components. 


\section{FMFM IMPLEMENTATION SPECIFICATIONS AT ECP}

The block diagram of the BDMS equipment installation layout on the HEU blending system at ECP is shown in Fig. 11; a typical BDMS representing for one leg of HEU blending tee is shown in Fig. 12. The blending system process pipes directly support the FMFM equipment. The process pipes where the BDMS is installed are about $1.25 \mathrm{~m}$ off the floor in order to have an easy access to the equipment for maintenance. The major FMFM assembly dimensions and approximate weights are given in Table 1 .

An enclosure surrounds the BDMS equipment to control access to the area for the health and safety considerations. The facility radiation dose rate requirement $(<0.3 \mathrm{mrem} / \mathrm{h}$ at $1 \mathrm{~m}$ from the surface of the equipment housing the ${ }^{252} \mathrm{Cf}$ sources) was met by the design of the SM assemblies and was verified by the certification measurements.

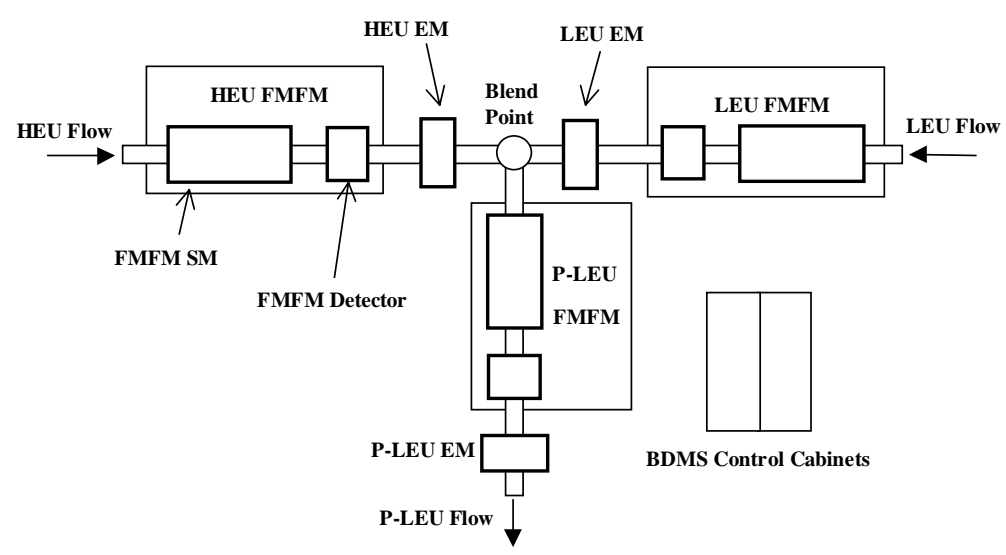

Fig. 11. Block diagram of the BDMS equipment installation on the HEU blending system at ECP.

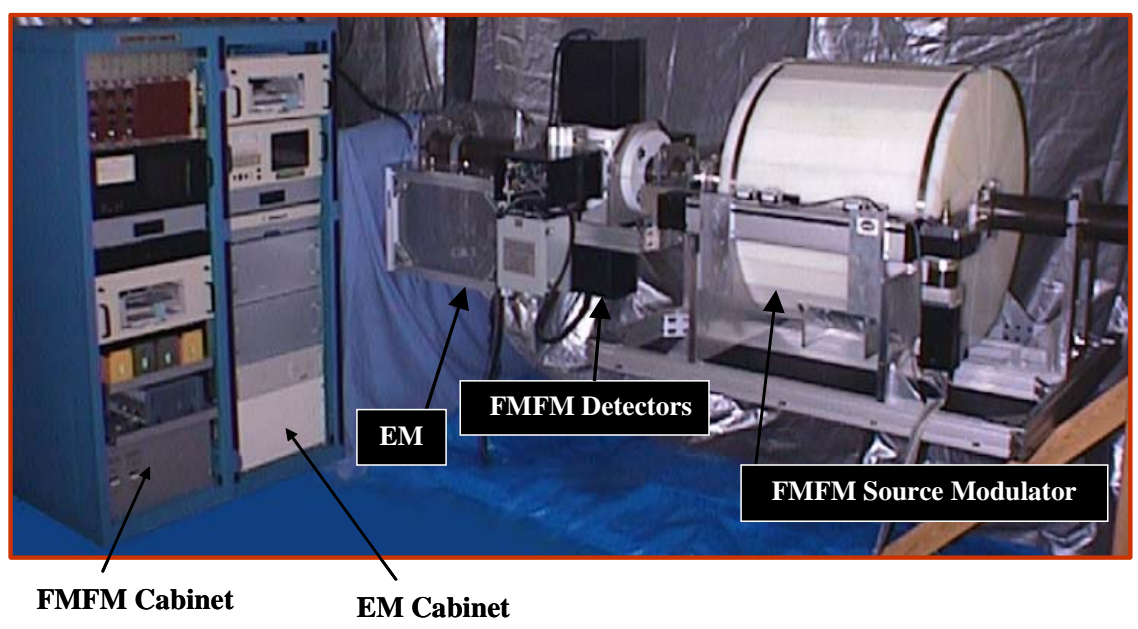

Fig. 12. The BDMS for the HEU blending tee leg. 
Table 1. FMFM assembly dimensions and weights

\begin{tabular}{lccc}
\hline \multicolumn{1}{c}{ Major assembly } & $\begin{array}{c}\text { Number of } \\
\text { assemblies }\end{array}$ & $\begin{array}{c}\text { Assembly dimensions, } \\
\text { length } \times \text { width } \times \text { height }(\mathrm{cm})\end{array}$ & Weight per assembly $(\mathrm{kg})$ \\
\hline Control cabinet & 1 & $58 \times 80 \times 190$ & 175 \\
Source modulator assembly & 3 & $137 \times 105 \times 92$ & 740 \\
Detector assembly & 3 & $58 \times 91 \times 91$ & 194 \\
\hline
\end{tabular}

\subsection{FMFM ${ }^{252}$ Cf NEUTRON SOURCES}

The SM on each leg of the blending system uses a total of four neutron sources. Each source contains $3 \mu \mathrm{g}$ of ${ }^{252} \mathrm{Cf}$ (half-life $\sim 2.65$ years). The sources provide total about $2.6 \times 10^{7}$ neutrons per second for the fission activation of the $\mathrm{UF}_{6}$ gas flow under the SM. As shown in Fig. 2, the sources are installed in the SM in polyethylene source plugs; four source plugs are evenly distributed around the SM. The radial locations of the sources were determined from the Monte Carlo modeling studies for maximizing the thermal neutron flux under the SM [5]. The sources need to be replaced about every 2 years to maintain the performance of the FMFM.

\subsection{UF $_{6}$ GAS PRESSURE}

The recommended $\mathrm{UF}_{6}$ gas pressure range for operation of the FMFM equipment is between 50 and 60 Torr (regulated) at the locations where the FMFM equipment is installed.

\subsection{FMFM FLOW REGIME OPERATIONS AND UF 6 GAS VELOCITY}

The FMFM can operate with either laminar or turbulent $\mathrm{UF}_{6}$ gas flow. At ECP, the FMFM is designed to measure the laminar flow of the HEU leg and the turbulent flow of the LEU and P-LEU legs. Table 2 specifies the range of gas velocities that the FMFM can measure.

Table 2. $\mathrm{UF}_{6}$ gas velocity ranges for FMFM operation

\begin{tabular}{lc}
\hline \multicolumn{1}{c}{ Flow regime } & Flow velocity range $(\mathrm{m} / \mathrm{s})$ \\
\hline Laminar & 0.02 to 0.2 \\
Turbulent & 1.5 to 5.0 \\
\hline
\end{tabular}

\subsection{FMFM PERFORMANCE PARAMETERS}

Table 3 shows the range of variables over which the FMFM is designed to operate, along with their measurement uncertainty. 
Table 3. FMFM flow measurement range and associated uncertainty

\begin{tabular}{llc}
\hline Flow parameter & Measurement range & Uncertainty (\%) \\
\hline Gas velocity, m/s & & \\
HEU leg & 0.02 to 0.2 & \pm 5 \\
LEU leg & 1 to 5 & \pm 5 \\
P-LEU leg & 1 to 5 & \pm 5 \\
Fissile mass flow, g/s & & \pm 25 \\
HEU leg & 0.10 to 1.0 & \pm 25 \\
LEU leg & 0.05 to 0.5 & \pm 25 \\
P-LEU leg & 0.15 to 1.5 & \\
\hline
\end{tabular}

\subsection{RECOMMENDED FMFM EQUIPMENT INSTALLATION CONFIGURATION AT ECP}

This section describes the recommended installation configuration for all major FMFM components in the ECP facility. Figures 13 and 14 show the recommended installation configuration for the FMFM assemblies for the HEU, LEU, and P-LEU legs. The SM-to-detector separation distances, optimized for the process legs, are obtained from simulation modeling studies [2] to achieve the design performance (i.e., at a given shutter period and detector background, the time delay was optimized for the expected velocity range of measurements). The FMFM assemblies include the supplemental polyethylene neutron shielding, as shown in Figs. 13 and 14.

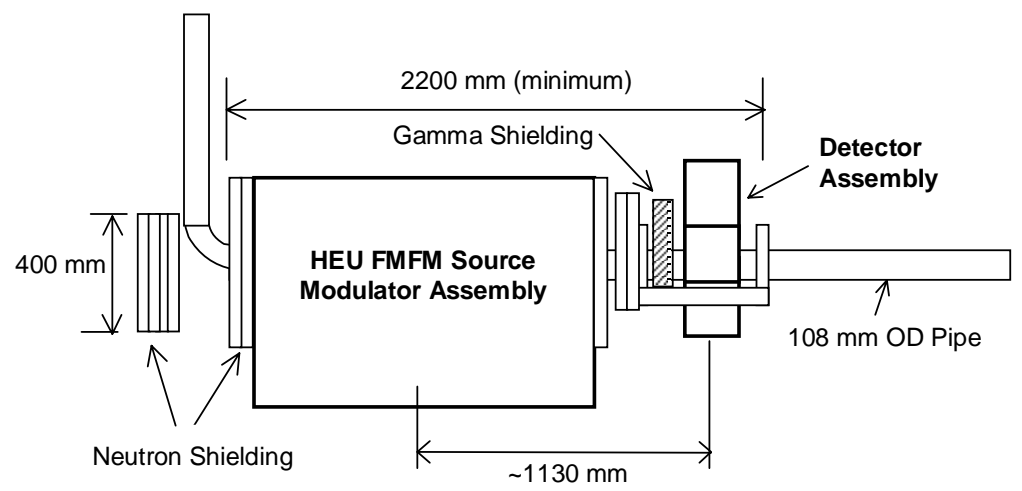

Fig. 13. Recommended FMFM installation configuration for HEU leg.

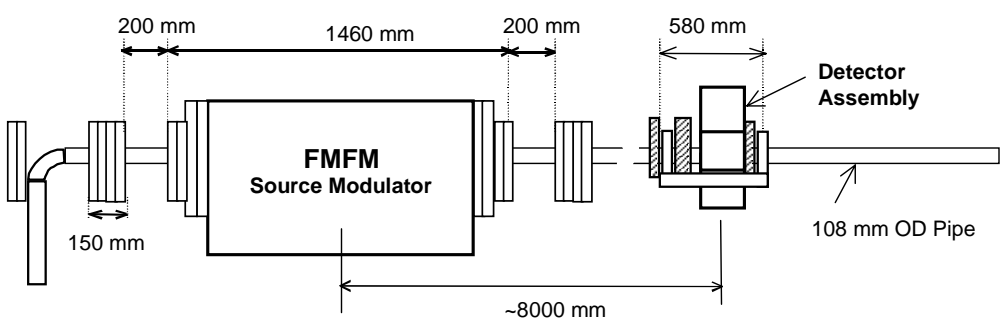

Fig. 14. Recommended FMFM installation configuration for the LEU and P-LEU legs. 
The recommended FMFM system configuration provides lower cross talk (background), such as minimum back shine from the SM to detectors, among the HEU, LEU, and P-LEU process legs. Also, as shown in Fig. 15, supplemental gamma shielding may be installed to further lower the background signal resulting from the sources in the SM on the HEU, LEU, and P-LEU legs.

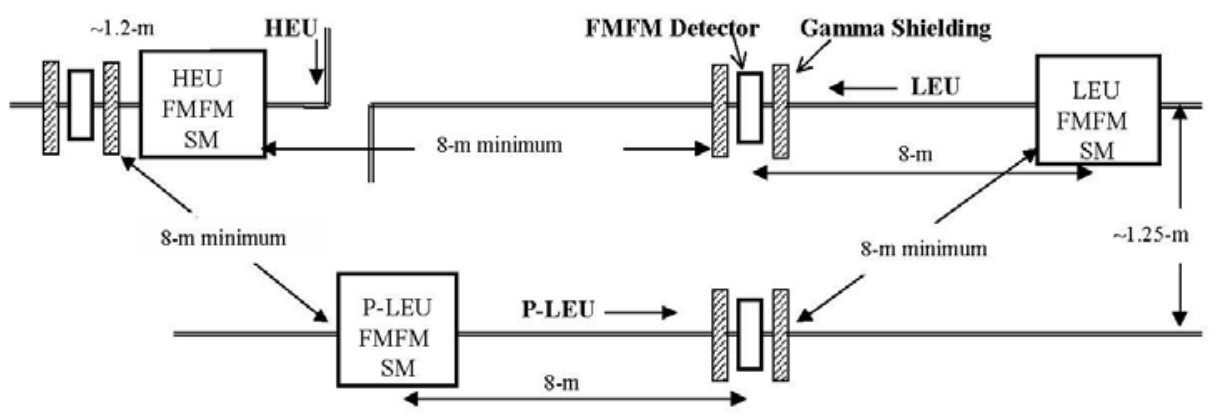

Fig. 15. Recommended FMFM installation configuration for all legs. The configuration is designed to reduce the cross talk between the sources in the SMs and the detectors. 


\section{BDMS IMPLEMENTATION STATUS}

In December 2001, after more than a month of complete operational testing at ORNL, the BDMS system equipment was packed in 32 crates and was shipped to ECP. The joint U.S. and ECP inventory of the crates was performed in late February 2002, and the required 30-day security inspection by MINATOM was completed. In March 2002, a Russian delegation participated in a week of training held at ORNL on the installation and operation of the BDMS equipment (see Fig. 16). The following topics were included in the training:

- introduction to the BDMS operation and major components and their functionalities;

- familiarization with the BDMS software and its operation and practice;

- hands-on installation and practice with a detailed implementation work plan for ECP;

- the BDMS sources and their replacement procedures;

- maintenance activities;

- introduction to the BDMS manuals; and

- introduction to the blend point check form, BP-1 for data removal, its use and practice.

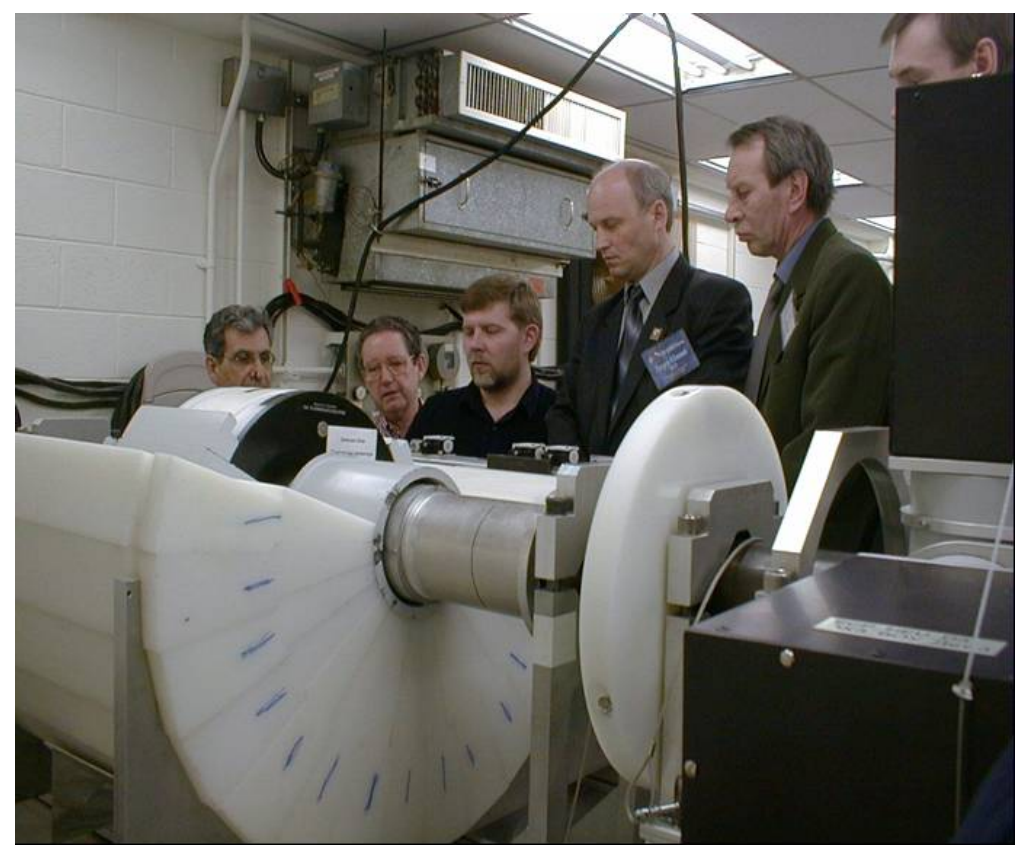

Fig. 16. The ECP BDMS training for the Russian delegation at ORNL, March 18-27, 2002. 
The recommended installation schedule and work plan were prepared by DOE and were provided to MINATOM.

The BDMS implementation was accomplished at ECP in February 2003. The BDMS hardware was successfully installed, and the system was calibrated and accepted for operation by MINATOM to be used by the DOE HEU Transparency Implementation Plan. The main BDMS implementation activities in February 2003 were to

- perform background measurements on the evacuated piping,

- complete calibration of the system, and

- work with the Russian Certification Commission selected by MINATOM to verify that the system met its criteria and that that the system was placed into transparency operation, and

- confirm operation of the installed system.

All four objectives were successfully accomplished, and the Russian Commission approved the ECP BDMS for transparency operation. 


\section{REFERENCES}

[1] J. March-Leuba, J. K. Mattingly, J. A. Mullens, T. E. Valentine, J. T. Mihalczo, and R. B. Perez, "Methodology for Interpretation of Fissile Mass Flow Measurements," Thirty-Eighth Annual Meeting of the Institute of Nuclear Materials Management, Phoenix, Arizona, July 20, 1997.

[2] D. Close et al., "HEU Transparency Implementation," LA-UR-98-4420, September 1998.

[3] T. Uckan, J. March-Leuba, J. Sumner, B. Vines, E. Mastal, and D. Powell, "Fissile Mass Flow Monitor Implementation for Transparency in HEU Blenddown at the Ural Electrochemical Integrated Plant (UEIP) in Novouralsk," JNMM 28(2), 11 (2000).

[4] T. Uckan et al., "Measurement Methodology of the Fissile Mass Flow Monitor for the HEU Transparency Implementation Instrumentation in Russia,"Forty-Second Annual Meeting of the Institute of Nuclear Materials Management, Indian Wells, California, July 20, 2001.

[5] J. K. Mattingly, J. March-Leuba, T. E. Valentine, J. T. Mihalczo, and T. Uckan, "Physics Design of Fissile Mass Flow Monitoring System," Thirty-Eighth Annual Meeting of the Institute of Nuclear Materials Management, Phoenix, Arizona, July 20, 1997. 



\section{INTERNAL DISTRIBUTION}

1. C. R. Brittain

2. J. Johnson, OTIC

3. J. A. March-Leuba

4-8. D. H. Powell

9. A. W. Riedy

10. J. E. Rushton

11. L. J. Satkowiak

12-16. T. Uckan

17. J. D. White

18-19. M. C. Wright

\section{EXTERNAL DISTRIBUTION}

20. Janie Benton, U. S. Department of Energy, NA-23/Germantown Building, 1000 Independence Avenue, S.W., Washington, DC 20585-1290

21. Dianna Blair, Sandia National Laboratory, International Programs, 10600 Research Road, Albuquerque, NM 87123

22. Cynthia Boggs, Argonne National Laboratory, 270 Corporate Square Bldg., 1000 Independence Ave., SW, Washington, DC 20585-0270

23. David Dougherty, U. S. Department of Energy, NA-241, 1000 Independence Avenue, S.W., Washington, DC 20585

24. Melvin Feather, II, SAIC, 20201 Century Blvd., Suite 300, Germantown, MD 20874

25-29. Joseph Glaser, U. S. Department of Energy, NA-23, 1000 Independence Avenue, S.W., Washington, DC 20585-1290

30. Tom Hill, Los Alamos National Laboratory, P.O. Box 1663, MS B228, Los Alamos, New Mexico, 87545

31. Dennis Meyers, U.SS. Department of Energy, NA-23/Germantown Building, 1000 Independence Avenue, S.W., Washington, DC 20585-1290

32. Calvin Moss, Los Alamos National Laboratory, P.O. Box 1663, MS B228, Los Alamos, New Mexico 87545

33. Radoslav Radev, Lawrence Livermore National Laboratory, P. O. Box 808, Livermore, CA 94551

34. Robert Richmond, Bechtel Nevada, P. O. Box 380, Suitland, MD 20752

35. Kurt Siemon, Jr., U. S. Department of Energy, NA-241, 1000 Independence Ave., S.W., Washington, DC 20585

36. David Wall, U. S. Department of Energy, NNSA, Y-12 Site Office, MS 8009, 200 Administration Road, Oak Ridge, TN 37831 
